\title{
Primary Imaging Test and Appropriate Biopsy Methods for Thyroid Nodules: Guidelines by Korean Society of Radiology and National Evidence-Based Healthcare Collaborating Agency
}

Eun Ju Ha, MD, PhD ${ }^{1}$, Hyun Kyung Lim, MD, PhD ${ }^{2}$, Jung Hyun Yoon, MD, $\mathrm{PhD}^{3}$, Jung Hwan Baek, MD, PhD ${ }^{4}$, Kyung Hyun Do, MD, PhD ${ }^{4}$, Miyoung Choi, RN, MPH, PhD Jin A Choi, $\mathrm{MPH}^{5}$, Min Lee, $\mathrm{MPH}^{5}$, Dong Gyu Na, MD, $\mathrm{PhD}^{6,7}$; the Korean Society of Thyroid Radiology (KSThR) and Korean Society of Radiology

${ }^{1}$ Department of Radiology, Ajou University School of Medicine, Suwon 16499, Korea; ${ }^{2}$ Department of Radiology, Soonchunhyang University Seoul Hospital, Seoul 04401, Korea; ${ }^{3}$ Department of Radiology and Research Institute of Radiological Science, Severance Hospital, Yonsei University College of Medicine, Seoul 03722, Korea; ' $D$ Department of Radiology and Research Institute of Radiology, University of Ulsan College of Medicine, Asan Medical Center, Seoul 05505, Korea; ${ }^{5}$ Division for Healthcare Technology Assessment Research, National Evidence-Based Healthcare Collaborating Agency, Seoul 04554, Korea; ${ }^{6}$ Department of Radiology, GangNeung Asan Hospital, Gangneung 25440, Korea; ${ }^{7}$ Department of Radiology, Human Medical Imaging and Intervention Center, Seoul 06524, Korea

The Korean Society of Radiology and the National Evidence-based Healthcare Collaborating Agency developed guidelines for primary imaging tests and appropriate biopsy methods for thyroid nodules. These guidelines were developed using an adaptation process by collaboration between the development committee and the working group. The development committee, composed of research methodology experts, established the overall plan and provided support about methodological strategies. The working group, composed of radiologist experts in thyroid imaging, wrote the proposals. The guidelines recommend neck ultrasound (US) as a first-line imaging modality for the diagnosis of thyroid nodules in patients with suspected nodules, and US-guided fine-needle aspiration as a primary method for histologic examination of thyroid nodules.

Keywords: Thyroid nodule; Ultrasound; Guideline; Fine-needle aspiration; Diagnosis; Recommendation

\section{INTRODUCTION}

Thyroid nodules are common in clinical practice. They

Received November 3, 2017; accepted after revision December 20, 2017.

This study was supported by the National Evidence-based Collaborating Agency (NECA-C-15-003) and the Korean Society of Radiology (NECA-S-15-002).

Corresponding author: Hyun Kyung Lim, MD, PhD, Department of Radiology, Soonchunhyang University Seoul Hospital, 59 Daesagwan-ro, Yongsan-gu, Seoul 04401, Korea.

- Tel: (822) 709-9396 - Fax: (822) 709-9066

- E-mail: merhen98@gmail.com

This is an Open Access article distributed under the terms of the Creative Commons Attribution Non-Commercial License (https://creativecommons.org/licenses/by-nc/4.0) which permits unrestricted non-commercial use, distribution, and reproduction in any medium, provided the original work is properly cited. are found in 4-8\% of the general population via palpation, in $19-67 \%$ of patients via ultrasound (US), and in $50 \%$ of autopsy specimens (1-6). Malignancies occur in 5-15\% of thyroid nodules $(3,7,8)$, and the incidence of thyroid cancer continues to increase worldwide due to various factors including genetic and environmental factors, development of medical devices, and the widespread implementation of healthcare programs. In Korea, thyroid cancer was the most common cancer in adults in 2013, being the most prevalent cancer in females and sixth most prevalent in males (9).

Various imaging techniques and procedures have been developed for the differential diagnosis of thyroid nodules. Imaging techniques include US, computed tomography (CT), magnetic resonance imaging (MRI), and positron emission tomography (PET). Procedures including palpation-guided fine-needle aspiration (FNA), US-guided FNA, and US-guided 
core needle biopsy (CNB) allow confirmation of nodules $(10,11)$. The need for standardized evidence-based clinical guidelines for the management of thyroid nodules has been proposed, and the Korean Society of Radiology (KSR) and the National Evidence-based Healthcare Collaborating Agency (NECA) organized a development committee and working group to develop such guidelines (12).

\section{Development of Korean Clinical Imaging Guidelines for Thyroid Nodules}

\section{Committee Composition}

The guideline development process involved collaboration between NECA and KSR. NECA is a national agency that provides evidence-based information about medical devices, medicines, and health technology obtained through objective and reliable analyses. The development committee included medical imaging experts, research methodology specialists, and clinical guideline specialists who support the overall planning and research methodology. They published a methodology for the guideline adaptation process in imaging diagnosis (12). The working group included expert members of the Korean Society of Thyroid Radiology (KSThR). KSThR is an organization composed of thyroid radiologists in Korea that is primarily involved in the diagnosis and nonsurgical treatment of thyroid nodules. KSThR has published several sets of guidelines for thyroid imaging $(11,13)$, biopsy $(10,14)$, and radiofrequency ablation (15). The working group participated in the guideline development process and wrote recommendations (12).

\section{Adaptation Process of the Guideline}

The guideline development process employed an adaptation methodology for Korean clinical imaging guidelines (K-CIG) established by the development committee (12).

\section{Defining Key Questions}

The Key Questions selected by the working group were reviewed by the development committee and a consensus group composed of clinical experts. Two final Key Questions were identified:

1) What is the primary imaging test for diagnosis in patients with suspected thyroid nodules?

2) What is the appropriate biopsy method for thyroid nodules?

\section{Search for Guidelines}

A systematic search for guidelines was performed using international databases published up to July 2015, including Ovid-MEDLINE, Ovid-EMBASE, National Guideline Clearinghouse, Guideline International Network, and major domestic databases including KoreaMed, KMBASE, Korean Medical Guidelines and Information, and Korean Guideline Clearinghouse. The websites of major academic societies and institutions were also searched.

\section{Selection of Searched Guidelines}

A total of 352 and 207 studies addressed Key Questions 1 and 2, respectively. Guideline selection was performed independently based on predefined inclusion/exclusion criteria. After excluding duplicates, screening titles and abstracts, and reading the full texts of the remaining articles, 9 and 5 articles, respectively, were selected (Figs. 1, 2).

\section{Quality Appraisal of the Guidelines}

The selected guidelines underwent a quality appraisal process using the Korean Appraisal of Guidelines for Research and Evaluation II tool developed by the guideline development committee. Guidelines with a score of less than 50 in the "Rigour of Development" domain were not recommended by the development committee. An exception was the "ultrasonography and the ultrasoundbased management of thyroid nodules: consensus statement and recommendations" (13), which was selected despite its low score because it was established by domestic thyroidimaging experts. After this process, five guidelines each were selected for Key Questions 1 and 2 (Tables 1, 2).

\section{Grading the Level of Evidence and Drafting the Recommendation Document}

The working group members reviewed evidence literatures that supported the recommendations of the selected guidelines. Grading the level of evidence of each literatures was performed according to the evidence level criteria of the K-CIG (12). After discussion and comparison of recommendations and their evidence literatures of selected guidelines, draft recommendations were prepared by the working group.

\section{Agreement of the Recommendation Grades}

The draft written by working group was reviewed and discussed by the development committee. Then, together, both groups came to a consensus on the recommendations 


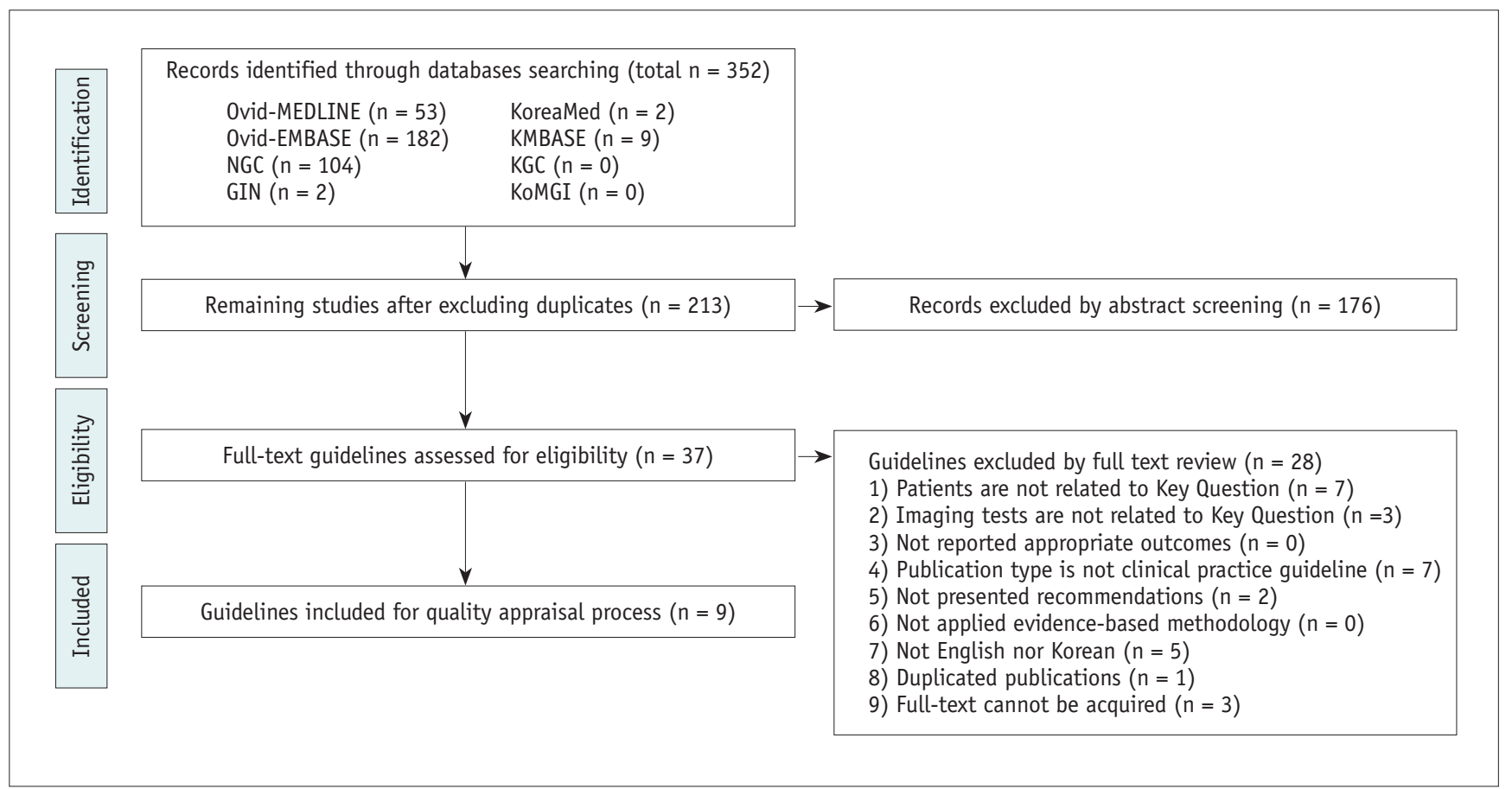

Fig. 1. Flow diagram of guideline selection (Key Question 1).

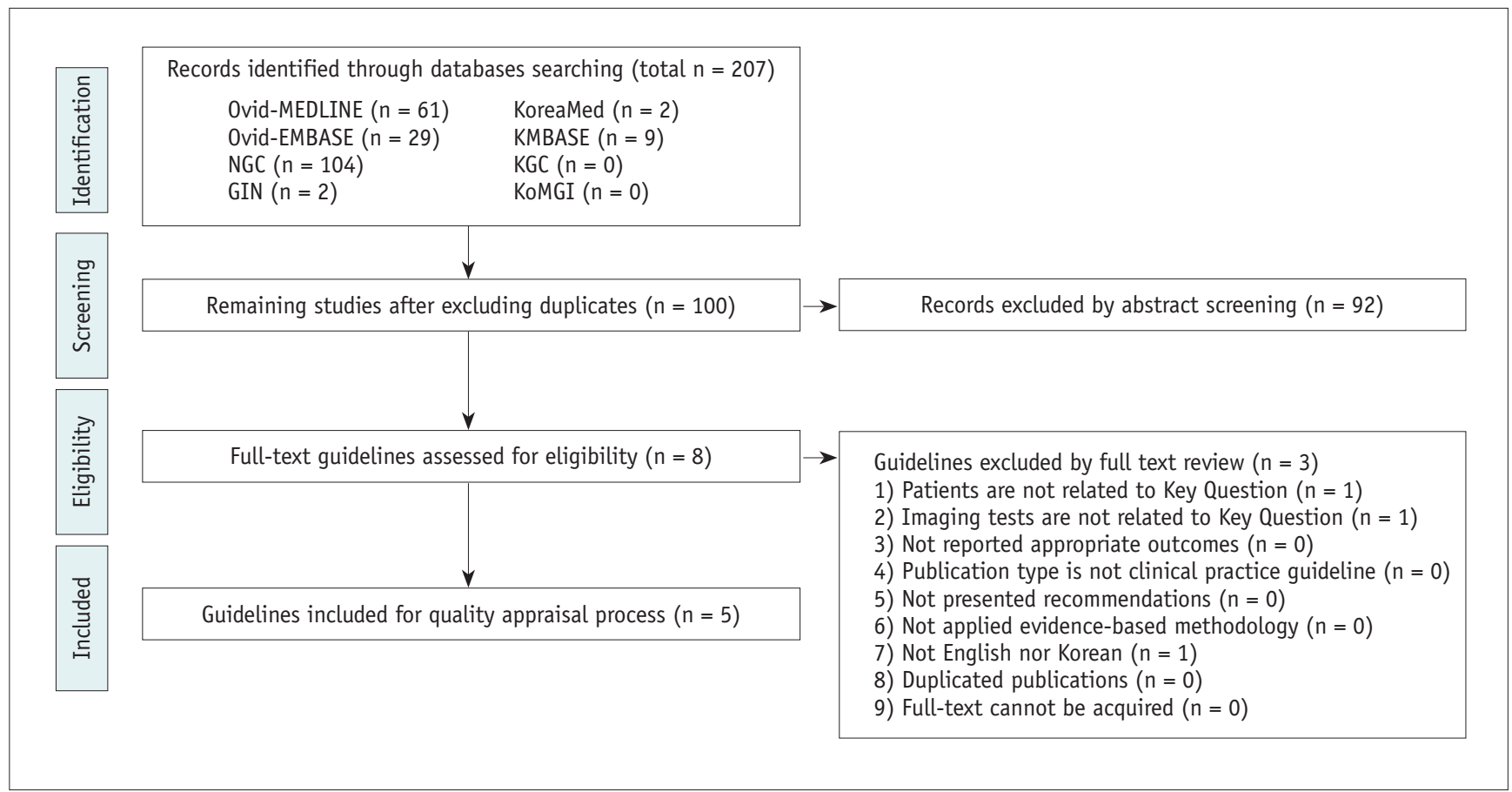

Fig. 2. Flow diagram of guideline selection (Key Question 2).

grade and the evidence level, according to the criteria of the K-CIG (12).

\section{Finalizing the Recommendation Document}

The Delphi method was used for formal consensus. The consensus group was composed of clinical imaging experts, clinical imaging guidelines-related academic societies (endusers), and research methodology experts. The agreement level for each recommendation, the grade of each recommendation, and the evidence level were rated from strongly disagree (level 1) to strongly agree (level 9). After two rounds of assessment, a consensus was reached. The 
average degree of agreement was 7.80 (standard deviation:

1.25) for recommendation 1 and 7.60 (standard deviation:

1.19) for recommendation 2.

\section{External Review and Approval of Clinical Guidelines}

Final recommendations were reviewed by clinical experts of a related medical society, the Korean Thyroid Association, and appropriate modifications were made.

\section{Recommendations}

\section{Key Question 1) What Is the Primary Imaging Test for Diagnosis in Patients with Suspected Thyroid Nodules?}

\section{[Recommendation 1]}

We recommend neck US for the diagnosis of thyroid nodules detected by imaging other than US or in patients with suspected thyroid nodules.

(recommendation grade $\mathrm{A}$, evidence level II)

\section{Evidence Summary}

After reviewing the guidelines for diagnosis and treatment of thyroid nodules, final five guidelines were selected (13, 16-19). In all five guidelines, neck US is recommended for diagnosis when a thyroid nodule is suspected. US is a highly sensitive diagnostic method for thyroid nodules and can be used to diagnose nodules and determine the need for FNA tests.

According to US and the US-based management of thyroid nodules: consensus statement and recommendations, high-resolution neck US is the most sensitive method for detecting thyroid nodules, and a neck US examination is recommended for diagnosis of suspected thyroid nodules (13). US is used to determine the size and morphologic features of the nodule, diagnose nodal involvement, and determine the need and possibility of US-guided FNA.

According to the American Thyroid Association (ATA) Management Guidelines for adult patients with thyroid nodules and differentiated thyroid cancer, US of the thyroid

Table 1. Recommendation Matrix of Existing Guidelines (Key Question 1)

\begin{tabular}{|c|c|c|c|}
\hline $\begin{array}{l}\text { Source Guidelines } \\
\text { (Publication Year) }\end{array}$ & $\begin{array}{c}\text { AGREE II } \\
\text { (Domain 3. Rigour } \\
\text { of Development) }\end{array}$ & Recommendation & $\begin{array}{l}\text { Grading of } \\
\text { Recommendation }\end{array}$ \\
\hline $\begin{array}{l}2015 \text { ATA Management Guidelines for } \\
\text { adult patients with thyroid nodules } \\
\text { and differentiated thyroid cancer } \\
\text { (2016) }\end{array}$ & 63 & $\begin{array}{l}\text { Thyroid sonography with survey of cervical lymph nodes } \\
\text { should be performed in all patients with known or } \\
\text { suspected thyroid nodules (strong recommendation, } \\
\text { high-quality evidence) }\end{array}$ & $\begin{array}{l}\text { Strong } \\
\text { recommendation, } \\
\text { high-quality } \\
\text { evidence }\end{array}$ \\
\hline $\begin{array}{l}\text { Thyroid carcinoma, version 2. } 2015 \\
\text { (NCCN Guideline) (2015) }\end{array}$ & 74 & $\begin{array}{l}\text { For thyroid nodules known or suspected on clinical or } \\
\text { imaging findings, US recommended (category } 2 \mathrm{~A} \text { ) }\end{array}$ & Category $2 \mathrm{~A}$ \\
\hline $\begin{array}{l}\text { BTA Guidelines for management of } \\
\text { thyroid cancer (2014) }\end{array}$ & 84 & $\begin{array}{l}\text { US is extremely sensitive examination for thyroid nodules. } \\
\text { It can be specific for diagnosis of thyroid carcinoma } \\
\text { (particularly papillary carcinoma), and aids decision } \\
\text { making about which nodules to perform FNA } \\
\text { i. All patients being investigated for possible thyroid } \\
\text { cancer should undergo US of neck in secondary care by } \\
\text { appropriate, competent practitioner }\end{array}$ & $\begin{array}{l}\text { Good practice } \\
\text { point }\end{array}$ \\
\hline $\begin{array}{l}\text { Ultrasonography and ultrasound- } \\
\text { based management of thyroid } \\
\text { nodules: consensus statement and } \\
\text { recommendations (2011) }\end{array}$ & 41 & $\begin{array}{l}\text { Among modern imaging modalities, high-resolution US } \\
\text { is most sensitive diagnostic modality for detection of } \\
\text { thyroid nodules and it is necessary to perform US for } \\
\text { nodules found after palpation. }\end{array}$ & Not available \\
\hline $\begin{array}{l}\text { AACE/AME/ETA Medical Guidelines } \\
\text { for clinical practice for diagnosis } \\
\text { and management of thyroid nodules } \\
\text { (2010) }\end{array}$ & 69 & $\begin{array}{l}\text { US evaluation is recommended for (grade B; BEL 3): } \\
\text { - Patients at risk for thyroid malignancy } \\
\text { - Patients with palpable thyroid nodules or MNGs } \\
\text { - Patients with lymphadenopathy suggestive of malignant } \\
\text { lesion }\end{array}$ & Grade B; BEL 3 \\
\hline
\end{tabular}

$\mathrm{AACE}=$ American Association of Clinical Endocrinologists, AGREE $=$ Appraisal of Guidelines for Research \& Evaluation, AME $=$ Associazione Medici Endocrinologi, ATA = American Thyroid Association, BEL = best evidence level, BTA = British Thyroid Association, ETA $=$ European Thyroid Association, FNA = fine-needle aspiration, MNG = multinodular goiter, NCCN = National Comprehensive Cancer Network, US = ultrasound 
gland and cervical lymph nodes is recommended in patients with suspected thyroid nodule or with incidental thyroid nodules detected via CT, MRI, or PET, for the diagnosis of thyroid nodule (17). It is recommended to confirm via neck US whether the lesion causing the symptom is related to the thyroid nodule; analyze the location, size, and morphological characteristics of the nodule; and ascertain whether neck lymph node metastasis has occurred (20-22).

The British Thyroid Association (BTA) Guidelines for the Management of Thyroid Cancer define neck US as a sensitive technique for the diagnosis of thyroid nodules and recommend neck US for differential diagnosis of papillary thyroid cancer (18). US is useful for determining the USguided FNA test according to the morphologic findings of the nodule and for increasing the diagnosis rate $(23,24)$.

According to the American Association of Clinical Endocrinologists (AACE), Associazione Medici Endocrinologi (AME), and European Thyroid Association (ETA) Medical Guidelines for clinical practice for the diagnosis and management of thyroid nodules, neck US is the most useful test for the detection and diagnosis of thyroid nodule, and for the determining changes in the thyroid parenchyma (16). These guidelines recommend US if a nodule needs to be touched or if there is suspicion of thyroidopathy (25), as well as to confirm thyroid pathology in the presence of palpable neck lymph nodes, because cervical lymph node metastasis due to asymptomatic thyroid cancer cannot be excluded.

The National Comprehensive Cancer Network (NCCN) Clinical Practice Guidelines for thyroid carcinoma (ver. 2) recommend neck US as a primary diagnostic test in patients with suspected thyroid nodules (19). US-guided FNA or US follow-up should be performed based on the comprehensive result of US finding of the initial scans, together with clinical findings, thyroid-stimulating hormone levels, and thyroglobulin levels.

\section{Considerations for Recommendations}

\section{Harms and Benefits}

Ultrasound is a very sensitive method for the detection and diagnosis of thyroid nodules. There is no risk of radiation exposure, and it is also possible to evaluate changes in the thyroid parenchyma and to examine lymph node status. US can also be used to determine the need for US-guided FNA, and improves the accuracy of diagnosis $(23,24)$.

However, thyroid nodules are very common and often asymptomatic. No US features that are specific to malignant thyroid nodules have been identified (7). Furthermore, several US findings are evident in both benign and malignant thyroid nodules $(20,24,26)$. This may lead to unnecessary FNA of benign nodules, which may lead to increased medical expenditures and unnecessary complications. However, the cost-effective aspect of the increase in medical expenditures may vary depending on whether or not medical insurance is applied. Finally, the US diagnosis of nodules can cause unnecessary worry and anxiety in patient.

\section{Acceptability and Applicability}

Neck US was chosen as the primary imaging method for patients with suspected or diagnosed thyroid nodule in five medical guidelines. As a result of the evaluation of domestic acceptability and applicability of these five guidelines, it was concluded that the applicability of neck US to the detection and diagnosis of thyroid nodules was reasonable.

\section{Radiation Dose}

Neck US: 0

\section{Key Question 2) What Is the Appropriate Biopsy Method for Thyroid Nodules?}

\section{[Recommendation 2]}

Ultrasound-guided FNA is recommended for histologic examination of thyroid nodules.

(recommendation A, evidence level II)

\section{Evidence Summary}

The five final guidelines were selected for appropriate testing methods for histologic diagnosis of thyroid nodules $(13,16-19)$. All five guidelines recommend FNA for histologic examination of thyroid nodules. Moreover, according to several comparisons between palpation-guided FNA and US-guided FNA $(23,27-29)$, the latter is better in terms of non-diagnostic results, specimen errors, and falsenegative results.

The BTA Guidelines for the management of thyroid cancer published in 2014 state that FNA is a valuable, costeffective preoperative test and that US-guided FNA improves the accuracy of diagnosis and reduces the probability of obtaining an inappropriate sample (18). In a prospective study of 215 patients, the non-diagnostic result rate $(21.4 \%)$ of the US-guided FNA was significantly lower than that of 
Table 2. Recommendation Matrix of Existing Guidelines (Key Question 2)

\begin{tabular}{|c|c|c|c|}
\hline $\begin{array}{l}\text { Source Guidelines } \\
\text { (Publication Year) }\end{array}$ & $\begin{array}{c}\text { AGREE II } \\
\text { (Domain } 3 . \\
\text { Rigour of } \\
\text { Development) }\end{array}$ & Recommendation & $\begin{array}{l}\text { Grading of } \\
\text { Recommendation }\end{array}$ \\
\hline $\begin{array}{l}2015 \text { ATA Management } \\
\text { Guidelines for } \\
\text { adult patients with } \\
\text { thyroid nodules and } \\
\text { differentiated thyroid } \\
\text { cancer (2016) }\end{array}$ & 63 & $\begin{array}{l}\text { (a) FNA is procedure of choice in evaluation of thyroid nodules, when } \\
\text { clinically indicated (strong recommendation, high-quality evidence) }\end{array}$ & $\begin{array}{l}\text { Strong } \\
\text { recommendation, } \\
\text { high-quality } \\
\text { evidence }\end{array}$ \\
\hline $\begin{array}{l}\text { Thyroid carcinoma, } \\
\text { version 2. } 2015 \text { (NCCN } \\
\text { Guideline) (2015) }\end{array}$ & 74 & THYR-1: consider FNA based on clinical and sonographic features & Category $2 \mathrm{~A}$ \\
\hline $\begin{array}{l}\text { BTA Guidelines for } \\
\text { management of } \\
\text { thyroid cancer } \\
(2014)\end{array}$ & 84 & $\begin{array}{l}\text { i. US appearances that are indicative of benign nodule (U1-2) should be } \\
\text { regarded as reassuring not requiring FNA cytology, unless patient has } \\
\text { statistically high risk of malignancy (chapter } 3.7)(2++, B) \\
\text { ii. If US appearances are equivocal, indeterminate or suspicious of } \\
\text { malignancy (U3-5), US guided FNA should follow }(2++, B)\end{array}$ & $(2++, B)$ \\
\hline $\begin{array}{l}\text { Ultrasonography } \\
\text { and ultrasound- } \\
\text { based management } \\
\text { of thyroid nodules: } \\
\text { consensus statement } \\
\text { and recommendations } \\
\text { (2011) }\end{array}$ & 41 & $\begin{array}{l}\text { We recommend performing FNA for nodule of any size that has suspicious } \\
\text { malignant findings if FNA is feasible and nodule is larger than } 5 \mathrm{~mm} \text { in } \\
\text { size. For nodule smaller than } 5 \mathrm{~mm} \text {, selective FNA can be done according } \\
\text { to patient's risk factors and experience of radiologists. } \\
\text { If nodule has indeterminate findings on US and it is larger than } 1 \mathrm{~cm} \text { in } \\
\text { diameter, then performing FNA is recommended due to fact that possibility } \\
\text { of malignancy cannot be excluded. If nodule has indeterminate findings } \\
\text { and it is } 1 \mathrm{~cm} \text { or less in size, then FNA biopsy is not necessary and follow- } \\
\text { up US would suffice. If benign appearing nodule is larger than } 1 \mathrm{~cm} \text {, then } \\
\text { we recommend performing follow-up US in two years and thereafter at } \\
3-5 \text { year intervals. If benign appearing nodule (i.e., spongiform nodule) } \\
\text { is larger than } 2 \mathrm{~cm} \text {, then selective FNA biopsy can be done. Neither FNA } \\
\text { nor follow up US is necessary for spongiform nodule and benign appearing } \\
\text { nodule } 1 \mathrm{~cm} \text { or less in diameter. }\end{array}$ & Not available \\
\hline $\begin{array}{l}\text { AACE/AME/ETA Medical } \\
\text { Guidelines for clinical } \\
\text { practice for diagnosis } \\
\text { and management of } \\
\text { thyroid nodules (2010) }\end{array}$ & 69 & $\begin{array}{l}\text { 3.7.2.1. How to select nodule(s) for FNA biopsy (grade B; BEL 3): } \\
\text { 1) FNA biopsy is recommended for nodule(s): } \\
\text { - Of diameter larger than } 1 \mathrm{~cm} \text { that is solid and hypoechoic on US } \\
\text { - Of any size with US findings suggestive of extracapsular growth or } \\
\text { metastatic cervical lymph nodes } \\
\text { - Of any size with patient history of neck irradiation in childhood or } \\
\text { adolescence; PTC, MTC, or MEN } 2 \text { in first-degree relatives; previous } \\
\text { thyroid surgery for cancer; increased calcitonin levels in absence of } \\
\text { interfering factors } \\
\text { - Of diameter smaller than } 10 \text { mm along with US findings associated with } \\
\text { malignancy (see section } 3.7 .1 .2 . \text { ); coexistence of } 2 \text { or more suspicious } \\
\text { US criteria greatly increases risk of thyroid cancer } \\
\text { 2) Nodules that are hot on scintigraphy should be excluded from FNA } \\
\text { biopsy (see difference in recommendations for children; section 8.4.) } \\
\text { 3.7.2.2. FNA biopsy of multinodular glands } \\
\text { 1) It is rarely necessary to biopsy more than } 2 \text { nodules when they are } \\
\text { selected on basis of previously described criteria (grade D) } \\
\text { 2) If radioisotope scan is available, do not biopsy hot areas } \\
\text { (grade B; BEL 4) }\end{array}$ & $\begin{array}{l}\text { 3.7.2.1. grade B; } \\
\text { BEL 3 } \\
\text { 3.7.2.2. grade D, } \\
\text { grade B; BEL } 4\end{array}$ \\
\hline
\end{tabular}

MEN = multiple endocrine neoplasia, $\mathrm{MTC}=$ medullary thyroid cancer, PTC = papillary thyroid cancer 
palpation-guided FNA (32.4\%), and the false negative result of US-guided FNA (5.6\%) was also significantly lower than that of palpation-guided FNA (15.8\%) (23).

The ATA Management Guidelines for adult patients with thyroid nodules and differentiated thyroid cancer strongly recommend FNA as the most accurate and cost-effective test for evaluating thyroid nodules (17). In a retrospective study, US-guided FNA had a significantly low non-diagnostic rate $(3.5 \%)$ and false-negative rate $(1 \%)$, compared to palpation-guided FNA (8.7\% and 2.3\%, respectively) (30). Particularly in cases of cystic, untouchable, or deep-located nodules, US-guided FNA is recommended because of the high probability of non-diagnostic result and sample errors. However, if the nodules are palpable and have a solid component, both US-guided FNA and palpation-guided FNA can be used. The diagnostic sensitivity, specificity, and accuracy of US-guided FNA were $97.1 \%, 100 \%$, and $75.9 \%$, respectively $(29,30)$.

The ultrasonography and the ultrasound-based management of thyroid nodules: consensus statement and recommendations (13) recommend performing US-guided FNA for histological diagnosis but do not cite any specific evidence.

The AACE/AME/ETA Medical Guidelines for clinical practice for the diagnosis and management of thyroid nodules published in 2010 recommend that the diagnosis of thyroid nodules should be based on the results of US and FNA, and that FNA should be done under US guidance to increase reliability and reduce the non-diagnostic result rate (16). US-guided FNA is strongly recommended when nodules are not palpable or are multinodular, when patients are obese, and/or when cervical muscles are highly developed (27, 28, 30-33). In one prospective study of 386 patients, US-guided FNA showed significantly lower non-diagnostic rate (12.5\%) than that of palpation-guided FNA (27.2\%) (27).

The NCCN Clinical Practice Guidelines for thyroid carcinoma (ver. 2) recommend that FNA should be performed for histologic diagnosis if the US findings meet the indication (19), particularly when unsuitable specimens or non-diagnostic results are obtained from previous FNAs conducted on solid nodules. However, they cite no specific evidence.

\section{Considerations for Recommendations}

\section{Harms and Benefits}

Ultrasound-guided FNA of thyroid nodules is a relatively easy and safe procedure, and is more accurate and less complicated than palpation-guided FNA $(23,27-29)$. Therefore, it can be performed by any doctor who specializes in thyroid.

However, the rate of non-diagnostic results depends on various factors such as technical proficiency of the practitioner, processing errors, and internal factors of the nodule itself. Therefore, efforts should be made to minimize non-diagnostic results (13). Recent reports have indicated that US-guided CNB may be an alternative to FNA in the case of nodules with non-diagnostic results in previous US-guided FNA $(34,35)$. The reported complication rate of US-guided FNA were $0-8.6 \%$, and most complications were hematoma around the thyroid gland, edema of the thyroid gland, and temporary changes in the voice. Severe complications requiring hospitalization were rare. Practitioners should be familiar with the appropriate preparation, prevention, and treatment methods to avoid complications in patients with a bleeding tendency. Unnecessary US-guided FNA for benign nodules can increase patient anxiety, and lead to unnecessary medical expenditures.

\section{Acceptability and Applicability}

Ultrasound-guided FNA was recommended as an appropriate histologic examination of thyroid nodules in all five medical guidelines. It was concluded that the domestic acceptability and applicability of the five guidelines were acceptable.

\section{Radiation Dose \\ Neck US: 0}

\section{SUMMARY}

These are the first evidence-based clinical imaging guidelines for thyroid imaging in Korea, and was developed using an adaptation process. The guidelines recommend that neck US as the first-line imaging modality for diagnosing thyroid nodules detected by imaging modalities other than US or in patients with suspected thyroid nodules, and US-guided FNA for primary histologic examination of thyroid nodules. We expect that these recommendations will be helpful in the clinical practice in the management of thyroid nodules.

\section{Acknowledgments}

The author gratefully acknowledged the KTA for reviewing the final recommendation document. 


\section{REFERENCES}

1. Vander JB, Gaston EA, Dawber TR. The significance of nontoxic thyroid nodules. Final report of a 15-year study of the incidence of thyroid malignancy. Ann Intern Med 1968;69:537-540

2. Tunbridge WM, Evered DC, Hall R, Appleton D, Brewis M, Clark $F$, et al. The spectrum of thyroid disease in a community: the Whickham survey. Clin Endocrinol (Oxf) 1977;7:481-493

3. Mandel SJ. A 64-year-old woman with a thyroid nodule. JAMA 2004;292:2632-2642

4. Mortensen JD, Woolner LB, Bennett WA. Gross and microscopic findings in clinically normal thyroid glands. J Clin Endocrinol Metab 1955;15:1270-1280

5. Guth S, Theune U, Aberle J, Galach A, Bamberger CM. Very high prevalence of thyroid nodules detected by high frequency $(13 \mathrm{MHz})$ ultrasound examination. Eur J Clin Invest 2009;39:699-706

6. Tan GH, Gharib H. Thyroid incidentalomas: management approaches to nonpalpable nodules discovered incidentally on thyroid imaging. Ann Intern Med 1997;126:226-231

7. Papini E, Guglielmi R, Bianchini A, Crescenzi A, Taccogna $S$, Nardi $F$, et al. Risk of malignancy in nonpalpable thyroid nodules: predictive value of ultrasound and color-Doppler features. J Clin Endocrinol Metab 2002;87:1941-1946

8. Nam-Goong IS, Kim HY, Gong G, Lee HK, Hong SJ, Kim WB, et al. Ultrasonography-guided fine-needle aspiration of thyroid incidentaloma: correlation with pathological findings. Clin Endocrinol (Oxf) 2004;60:21-28

9. Korean Statistical Information Service. Web site. http://kosis. $\mathrm{kr} /$ statisticsList/statisticsList_01List.jsp?vwcd=MT_ZTITLE\&pa rmTabId=M_01_01\#SubCont. Published 2015. Accessed August 25, 2017

10. Na DG, Baek JH, Jung SL, Kim JH, Sung JY, Kim KS, et al.; Korean Society of Thyroid Radiology (KSThR) and Korean Society of Radiology. Core needle biopsy of the thyroid: 2016 consensus statement and recommendations from Korean Society of Thyroid Radiology. Korean J Radiol 2017;18:217237

11. Shin JH, Baek JH, Chung J, Ha EJ, Kim JH, Lee YH, et al.; Korean Society of Thyroid Radiology (KSThR) and Korean Society of Radiology. Ultrasonography diagnosis and imagingbased management of thyroid nodules: revised Korean Society of Thyroid Radiology consensus statement and recommendations. Korean J Radiol 2016;17:370-395

12. Choi SJ, Jeong WK, Jo AJ, Choi JA, Kim MJ, Lee M, et al. Methodology for developing evidence-based clinical imaging guidelines: joint recommendations by Korean Society of Radiology and National Evidence-Based Healthcare Collaborating Agency. Korean J Radiol 2017;18:208-216

13. Moon WJ, Baek JH, Jung SL, Kim DW, Kim EK, Kim JY, et al.; Korean Society of Thyroid Radiology (KSThR); Korean Society of Radiology. Ultrasonography and the ultrasound-based management of thyroid nodules: consensus statement and recommendations. Korean J Radiol 2011;12:1-14

14. Lee YH, Baek JH, Jung SL, Kwak JY, Kim JH, Shin JH. Korean Society of Thyroid Radiology (KSThR); Korean Society of Radiology. Ultrasound-guided fine needle aspiration of thyroid nodules: a consensus statement by the korean society of thyroid radiology. Korean J Radiol 2015;16:391-401

15. Na DG, Lee JH, Jung SL, Kim JH, Sung JY, Shin JH, et al.; Korean Society of Thyroid Radiology (KSThR); Korean Society of Radiology. Radiofrequency ablation of benign thyroid nodules and recurrent thyroid cancers: consensus statement and recommendations. Korean J Radiol 2012;13:117-125

16. Gharib H, Papini E, Paschke R, Duick DS, Valcavi R, Hegedüs $L$, et al.; AACE/AME/ETA Task Force on Thyroid Nodules. American Association of Clinical Endocrinologists, Associazione Medici Endocrinologi, and EuropeanThyroid Association medical guidelines for clinical practice for the diagnosis and management of thyroid nodules. Endocr Pract 2010;16 Suppl 1:1-43

17. Haugen BR, Alexander EK, Bible KC, Doherty GM, Mandel SJ, Nikiforov YE, et al. 2015 American Thyroid Association management guidelines for adult patients with thyroid nodules and differentiated thyroid cancer: the American Thyroid Association guidelines task force on thyroid nodules and differentiated thyroid cancer. Thyroid 2016;26:1-133

18. Perros P, Boelaert K, Colley S, Evans C, Evans RM, Gerrard $\mathrm{Ba} G$, et al.; British Thyroid Association. Guidelines for the management of thyroid cancer. Clin Endocrinol (Oxf) 2014;81 Suppl 1:1-122

19. National Comprehensive Cancer Network. Web site. https:// www.nccn.org/professionals/physician_gls/pdf/thyroid.pdf. Published 2015. Accessed August 14, 2015

20. Frates MC, Benson CB, Charboneau JW, Cibas ES, Clark OH, Coleman BG, et al.; Society of Radiologists in Ultrasound. Management of thyroid nodules detected at US: Society of Radiologists in Ultrasound consensus conference statement. Radiology 2005;237:794-800

21. Smith-Bindman R, Lebda P, Feldstein VA, Sellami D, Goldstein RB, Brasic N, et al. Risk of thyroid cancer based on thyroid ultrasound imaging characteristics: results of a populationbased study. JAMA Intern Med 2013;173:1788-1796

22. Brito JP, Gionfriddo MR, Al Nofal A, Boehmer KR, Leppin AL, Reading $C$, et al. The accuracy of thyroid nodule ultrasound to predict thyroid cancer: systematic review and meta-analysis. $J$ Clin Endocrinol Metab 2014;99:1253-1263

23. Cesur M, Corapcioglu D, Bulut S, Gursoy A, Yilmaz AE, Erdogan $N$, et al. Comparison of palpation-guided fineneedle aspiration biopsy to ultrasound-guided fine-needle aspiration biopsy in the evaluation of thyroid nodules. Thyroid 2006;16:555-561

24. Hambly NM, Gonen M, Gerst SR, Li D, Jia X, Mironov S, et al. Implementation of evidence-based guidelines for thyroid nodule biopsy: a model for establishment of practice standards. AJR Am J Roentgenol 2011;196:655-660

25. Solbiati L, Osti V, Cova L, Tonolini M. Ultrasound of thyroid, parathyroid glands and neck lymph nodes. Eur Radiol 
2001;11:2411-2424

26. Lee YH, Kim DW, In HS, Park JS, Kim SH, Eom JW, et al. Differentiation between benign and malignant solid thyroid nodules using an US classification system. Korean J Radiol 2011;12:559-567

27. Can AS, Peker K. Comparison of palpation-versus ultrasoundguided fine-needle aspiration biopsies in the evaluation of thyroid nodules. BMC Res Notes 2008;1:12

28. Deandrea M, Mormile A, Veglio M, Motta M, Pellerito R, Gallone $G$, et al. Fine-needle aspiration biopsy of the thyroid: comparison between thyroid palpation and ultrasonography. Endocr Pract 2002;8:282-286

29. Carmeci C, Jeffrey RB, McDougall IR, Nowels KW, Weigel RJ. Ultrasound-guided fine-needle aspiration biopsy of thyroid masses. Thyroid 1998;8:283-289

30. Danese D, Sciacchitano S, Farsetti A, Andreoli M, Pontecorvi A. Diagnostic accuracy of conventional versus sonographyguided fine-needle aspiration biopsy of thyroid nodules.
Thyroid 1998;8:15-21

31. Yang J, Schnadig V, Logrono R, Wasserman PG. Fine-needle aspiration of thyroid nodules: a study of 4703 patients with histologic and clinical correlations. Cancer 2007;111:306-315

32. Gharib H, Papini E. Thyroid nodules: clinical importance, assessment, and treatment. Endocrinol Metab Clin North Am 2007;36:707-735, vi

33. Wu HH, Jones JN, Osman J. Fine-needle aspiration cytology of the thyroid: ten years experience in a community teaching hospital. Diagn Cytopathol 2006;34:93-96

34. Baek JH. Current status of core needle biopsy of the thyroid. Ultrasonography 2017;36:83-85

35. Suh CH, Baek JH, Kim KW, Sung TY, Kim TY, Song DE, et al. The role of core-needle biopsy for thyroid nodules with initially nondiagnostic fine-needle aspiration results: a systematic review and meta-analysis. Endocr Pract 2016;22:679-688 